\title{
The Place of Joint Development in the Sustainable Arctic Governance
}

ShipArc2015: Joint WMU - IMO - Arctic Council International Conference on Safe and Sustainable Shipping in a Changing Arctic Environment

Malmo Sweden $25^{\text {th }}-27^{\text {th }}$ August 2015

Buba Bojang

PhD Student

School of Law

University of Aberdeen

UK 


\section{Contents:}

- Facts about the Arctic Ocean

- Maritime Boundary Delimitation: the Applicable laws

- The Legal Limitations and Gaps : UNCLOS and Geneva

- The llulissat Declaration VS Others

- The Place of Joint Development

- Proposed Regime Contents

- Conclusion 


\section{Facts about the Arctic}

- The Arctic Ocean comprises of: The Barents; Kara; Laptev; East Siberia, and Chukchi Seas,

- Continental shelf (4.5m square kilometres, half shallow extensions of land mass and half deep ocean floor)

- Ice is the main characteristic

- Semi-enclosed sea (Northwest and Northern passages)

- Eight coastal States (US Russia Canada Norway Denmark Sweden Finland and Iceland)

- Seven international boundaries that merits delimitation:

* 4 delimited

* 3 un-delimited (2 governed by the UNCLOS; the remainder by GCCS/CIL

- 2008 USGS on Arctic hydrocarbon potential:

* 25 provinces

* 7 located in disputed areas or straddle across boundaries

- The erosion of the ice cap; the long extended continental shelf, and the huge commercial potentials (oil and gas) 


\section{Maritime boundary delimitation : the Applicable Laws}

- Geneva Convention on the Continental Shelf 1958

* US; Canada, and Russia

- Customary International Law

- United Nations Convention on the Law of the Sea

* All Arctic States, Except US

- Article 298 (1) Declaration:

- Canada and Russia (removal of Arts. 15, 74 and 83 from all procedures)

* Denmark and Norway (non acceptance of Annex VII Tribunal)

* Finland (ICJ and ITLOS)

* Sweden (ICJ)

* Iceland (Annex V Conciliation) 


\section{The Legal Limitations and Gaps : UNCLOS and Geneva}

- Delimitation of maritime boundary (continental shelf) complicated by rules/ basis of claim:

* Natural Prolongation

* The 200NM

- declarations and statements and third party adjudicatory Process

- Lack of explicit rules for the exploitation of transboundary oil and gas resources or those found in overlapping claim areas/disputed areas

- Two main challenges: Delimitation and trans-boundary hydrocarbon 


\section{The Ilulissat Declaration VS Others}

- The llulissat Declaration:

* Acknowledge the changing nature of the Arctic and the potential exploitation of natural resources (oil and gas)

* Recall on the applicability of UNCLOS to the Arctic Ocean in terms of delimitation and delineation, the protection and preservation of the marine environment and other peaceful uses of the sea

* Conclude 'no need to develop a new comprehensive international legal regime to govern the Arctic Ocean'

- Promise to adopt appropriate rules when the need arise

- Others:

Treaty regime similar to the 1961 Antarctica treaty in order to resolve the conflicting claims by instituting a framework for joint governance.

* International treaty to establish an international sector or park

* The creation of an authority to place a moratorium on natural resource exploitation and development in the Arctic 


\section{The Place of Joint Development}

- the Arctic needs a regime that will strike a balance:

* economic imperative of natural resource exploitation and the social obligation to manage the environment

- Joint Development:

* cooperative mechanism for the joint utilisation shared natural resources (international rivers, trans-boundary fisheries, trans-boundary aquifers and transboundary oil and gas)

* Alternative to maritime boundary delimitation

* Expanding role from resource exploitation and apportionment to a more sophisticated mechanism for ocean management

* inclusion of marine environment protection provisions (art 23 of the UK/Norway Frigg Field Treaty; Nigeria and Sao Tome and Principe Treaty on joint development

* The Barents Sea treaty did not have similar explicit provision 


\section{Proposed Regime Contents}

- Joint Development Mechanism

* Treaty, draft articles/principles/soft law

* Bilateral and multilateral use

- Arctic Natural Resources Development Code

* Exploration

* Exploitation

- Decommissioning 


\section{Conclusion}

- Some thoughts:

* The Forces of Destruction in the Arctic

* Natural Resources are predicted to be the next generation Conflicts 
